\title{
Two new varieties in Stipa (Poaceae) from Central Asia
}

Marcin Nobis \& Arkadiusz Nowak

Two new varieties in Stipa (Poaceae) from Central Asia. - Acta Mus. Siles. Sci. Natur. 65: 278-280, 2016.

\begin{abstract}
The paper presents descriptions of two new taxa, Stipa $\times$ brevicallosa var. hissarensis and Stipa orientalis var. ladakhorum. Both of them differ from the nominal varieties in having densely pubescent (not glabrous or scabrous) leaves of vegetative shoots. First of the above mentioned taxa occurs in Tajikistan (Pamir Alai Mts) whereas the second in India (Western Himalayas). Images of type specimens of both taxa are provided.
\end{abstract}

Key words: feather grasses, var. nov., Tajikistan, India, Pamir Alai, Himalayas

\section{Introduction}

The genus Stipa L. is one of the largest genera in the family Poaceae in the Old World. It comprises over 150 species distributed in open grasslands and steppes, with species diversity in warm temperate regions over Europe, Asia and North Africa (Tzvelev 1976, Martinovský 1980, Nobis 2014, Nobis et al. 2016). It is worth noticing that species belonging to the genus that are new to science continue to be described. Approximately twenty species have been described in the last fifteen years from countries such as Bhutan, Spain, Morocco, Italy, Turkey, northern Africa, Kazakhstan, Kyrgyzstan, Mongolia, China, India and Tajikistan. Nevertheless, many regions, especially in mountains areas of Asia, still remain unexplored, and detailed studies are revealing new information on the distribution of feather grasses and new Stipa taxa (e.g. Noltie 1999, Kotukhov 2002, Nobis 2011, 2013, Nobis et al. 2014a, $2014 b, 2014 c, 2016)$. This paper is a result of revision of herbarium materials as well as field studies carried out in the mountains of Central Asia in 2007-2016. The aim of this paper is to describe two new taxa of Stipa which were found during our studies. Because both of them differ from the most similar taxa only in having densely pubescent (not glabrous or scabrous) leaves of vegetative shoots, we decided to described them in the rank of variety.

Stipa $\times$ brevicallosa M. Nobis (2013: 1340) var. hissarensis M. Nobis \& A. Nowak var. nov. (Fig. 1)

Type: Tajikistan, Hissar Mts (Pamir Alai) - "Zeravshan B region", steppe grassland on the right slope of Gabierud River valley, near Pormin settl. near Zeravshan village - ca. $2 \mathrm{~km} \mathrm{~S}$ of Jagnob river, alt. $1896 \mathrm{~m}$ a.s.1., $39^{\circ} 10^{\prime} 12.46^{\prime \prime} \mathrm{N}, 68^{\circ} 34^{\prime} 42.86^{\prime \prime E}, 25.05 .2015$, M. Nobis \& A. Nowak s.n. (holotype: KRA464720; isotypes: KRA464721, KRA464722, KRA464723, KRA464708).

Diagnosis: Stipa $\times$ brevicallosa var. hissarensis differs from Stipa $\times$ brevicallosa var. brevicallosa in having densely pubescent leaves of vegetative shoots vs. leaves glabrous respectively.

Distribution and ecology: Stipa $\times$ brevicallosa var. hissarensis is a Middle Asiatic mountain taxon, endemic to the western Pamir Alai Mts, known only from Tajikistan (Hissar and Zeravshan Mts). It grows on loess substrate ( $\mathrm{pH} 7.6$ ), on high mountain feather grass steppes, mainly at exposures of W-SW-S and at an altitude of 1850-2350 m. 


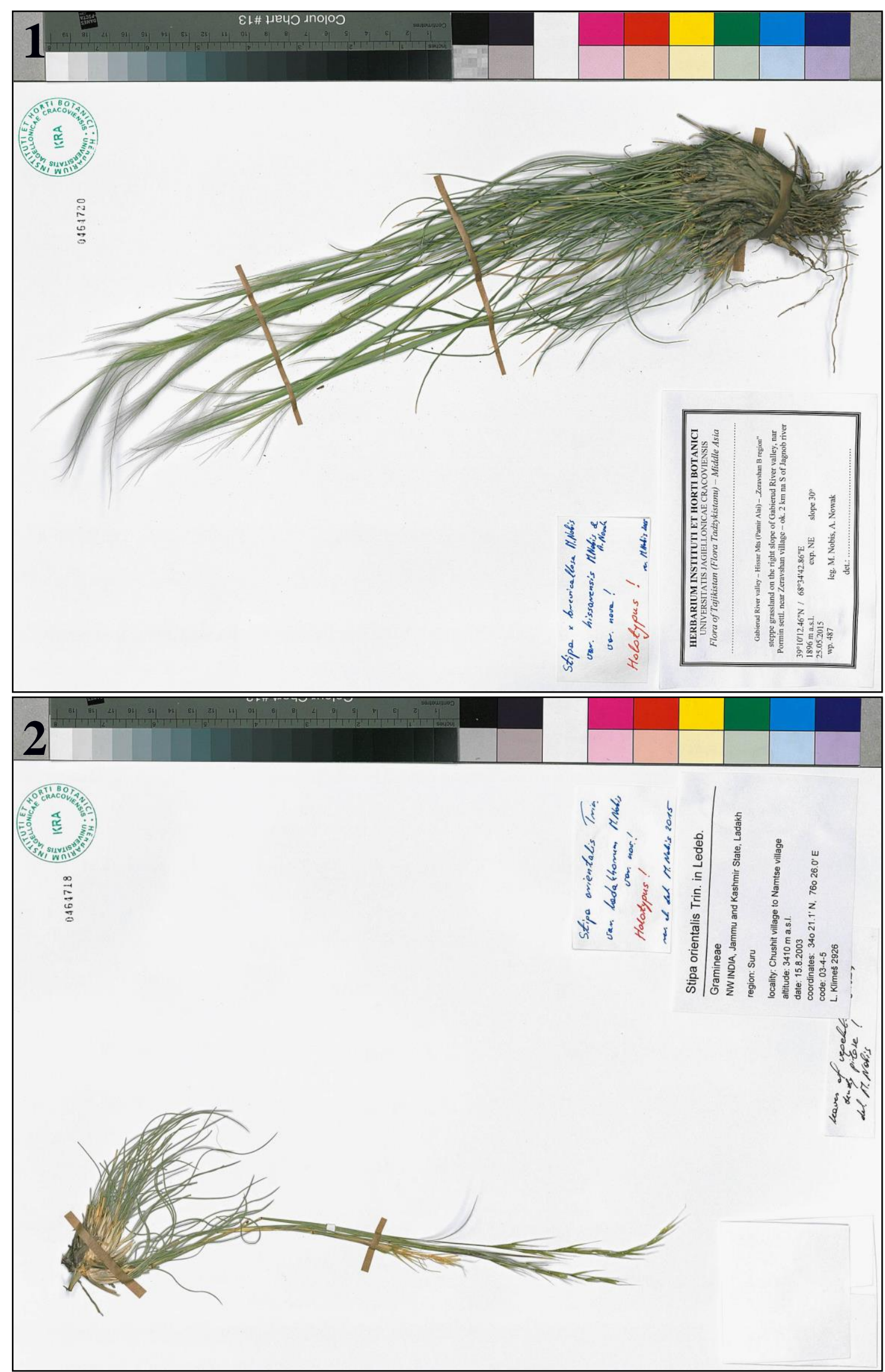

Figs 1-2: 1 - Holotype of Stipa $\times$ brevicallosa var. hissarensis (above). 2 - Holotype of Stipa orientalis var. ladakhorum (below) 
Other specimens studied: Tajikistan, Zeravshan Mts, high mountain steppe, between stones, on the left slope of the Iskanderdarya River valley, ca. $0.5 \mathrm{~km}$ E of Serimadarun lake (near Iskanderkul lake), alt. 2300-2350 m, incl. WSW, slope $5^{\circ}, 10.06 .2012$, M. Nobis s.n. (paratype: KRA464719).

\section{Stipa orientalis Trinius (1829: 83) var. ladakhorum M. Nobis var. nov. (Fig. 2)}

Type: NW India, Jammu and Kashmir State, Ladakh, Suru region, Chsshit village to Namtse villaeg, alt. $3410 \mathrm{~m}$ a.s.1., 34²1.1'N, 76²6.0'E, 15.08.2003, L. Klimeš 2926 (holotype: KRA464718).

Diagnosis: Stipa orientalis var. ladakhorum differs from Stipa orientalis var. orientalis in having densely pubescent leaves of vegetative shoots vs. leaves scabrous respectively.

Distribution and ecology: Stipa orientalis var. ladakhorum is known only from Jammu and Kashmir State in northern India (Western Himalayas). It is probable that the species may be found in the neighboring areas of Tibet, where similar habits occur. The species grows on rocks and in high mountain steppes, at elevation over $3000 \mathrm{~m}$ a.s.1.

Acknowledgements: This research was supported by the National Science Center (Poland), grant no. DEC2013/09/B/NZ8/03287.

\section{References}

Kotukhov Yu. (2002): Konspekt kovylei (Stipa L.) i kovylechkov (Ptilagrostis Griseb.) vostochnogo Kazakhstana (Kazakhstanskii Altai, Zaisanskaya kotlovina i Prialtaiskie khrebty). - Botanicheskie Issledovaniya Sibiri i Kazakhstana 8: 3-16.

Nobis M. (2011): Remarks on the taxonomy and nomenclature of the Stipa tianschanica complex (Poaceae), on the base of a new record for the flora of Tajikistan (Central Asia). - Nordic Journal of Botany 29: 194-199.

- (2013): Taxonomic revision of the Stipa lipskyi group (Poaceae: Stipa section Smirnovia) in the Pamir Alai and Tian-Shan Mountains. - Plant Systematics and Evolution 299: 1307-1354.

- (2014): Taxonomic revision of the Central Asian Stipa tianschanica complex (Poaceae) with particular reference to the epidermal micromorphology of the lemma. - Folia Geobotanica 49: 283-308.

Nobis M., Ebel A.L., Nowak A., Turginov O.T., Kupriyanov A.N., Nobis A., Olonova M.V., Paszko B., Piwowarczyk R., Chen W.L., et al. (2014a): Contribution to the flora of Asian and European countries: new national and regional vascular plant records, 2. - Acta Botanica Gallica: Botany Letters 161(2): 209-221.

Nobis M. \& Gudkova P.D. (2016): Taxonomic notes on feather grasses (Poaceae: Stipa) from eastern Kazakhstan with typification of seven names and one new combination. - Phytotaxa 245(1): 31-42.

Nobis M., Nobis A., Klichowska E., Nowak A., Nowak S. \& Gudkova P.D. (2016): Stipa dickorei sp. nov. (Poaceae), three new records and a checklist of feather grasses of China. - Phytotaxa 267(1): 29-39.

Nobis M., Nobis A. Nowak A. \& Nowak S. (2014c): Stipa klimesii (Poaceae) a new species from Western Himalayas (India). - Phytotaxa 174(3): 173-180.

Nobis M., Nowak A., Nobis A., Paszko B., Piwowarczyk R., Nowak S. \& Plášek V. (2014b): Contribution to the flora of Asian and European countries: new national and regional vascular plant records. - Acta Botanica Gallica: Botany Letters 161: 81-89.

Noltie H.J. (1999): Notes relating to the flora of Bhutan: XXXVIII. Gramineae I, tribe Stipeae. - Edinburgh Journal of Botany 56: 285-292.

Martinovský J.O. (1980): Stipa L. - In: Tutin T.G., Heywood V.H., Burges N.A., Moore D.M., Valentine D.H., Walters S.M. \& Webb D.A. (eds). Flora Europaea, 5. Cambridge Univ. Press, pp. 247-252.

Trinius C.B. (1829): Stipa L. - In: Ledebur K.F. von (ed.) Flora Altaica, 1. Berolini, Typis impensis G. Reimeri, pp. 80-84.

Tzvelev N.N. (1976): Zlaki SSSR. Nauka, Leningrad, 788 pp.

Authors' addresses: Marcin Nobis, Institute of Botany, Jagiellonian University, Kopernika 27,

31-501 Kraków, Poland.

E-mail: m.nobis@uj.edu.pl (corresponding author)

Arkadiusz Nowak, Department of Biosystematics, Laboratory of Geobotany and Plant

Conservation, Opole University, Oleska St. 22, 45-052 Opole, Poland;

Department of Biology \& Ecology, University of Ostrava, Chittussiho 10, 71000 Ostrava,

Czech Republic. 